\title{
Pelatihan Alat Pemotong Bambu Otomatis Berbasis Mikrokontroler Menuju Kampung Produktif di Desa Ngajum Gunung Kawi Malang
}

\author{
Suastika Yulia Riska', Suci Imani Putri', Widya Adhariyanty Rahayu ${ }^{3}$ \\ STMIK ASIA Malang \\ e-mail: ${ }^{1}$ suastikayr@gmail.com, ${ }^{2}$ s.imaniputri@gmail.com, ${ }^{3}$ widyariyanty@gmail.com
}

\begin{abstract}
ABSTRAK. Desa Ngajum Gunung Kawi Kabupaten Malang Jawa Timur terdapat banyak home industri produksi potongan bambu. Pemasaran yang luas, mengakibatkan pekerja kuwalahan dalam proses pemotongan bambu. Proses pemotongan bambu dilakukan secara manual, sehingga membutuhkan waktu produksi yang lama, tingginya resiko kecelakaan kerja, dan tenaga manusia yang lebih banyak. Pelatihan yang dilakukan bekerja sama dengan Mitra untuk memecahkan permasalahan yang di hadapi Mitra, antara lain, pelatihan penggunaan alat pemotong bambu otomatis, pelatihan dan pendampingan maintenance alat pemotong bambu otomatis, serta pelatihan dan pendampingan manajemen produksi potongan bambu. Alat yang dibuat antara lain alat pemotong bambu sebagai pengganti proses pemotongan manual dan alat penghalus bambu setelah bambu terpotong pada tahap akhir. Perancangan kedua alat tersebut dapat memberikan pembaharuan ilmu dari segi IPTEK yaitu implementasi mikrokontroler sebagai pengendali alat, meminimalisasi kecelakaan kerja saat produksi pemotongan bambu, dan mengoptimalkan hasil produksi dari segi waktu produksi. Hasil produksi mengalami peningkatan setelah menggunakan alat pemotong dan penghalus bamboo otomatis, yaitu $25 \mathrm{~kg} / \mathrm{hari}$ menjadi $100 \mathrm{~kg} / \mathrm{hari}$.
\end{abstract}

Kata kunci: bambu, mikrokontroler, pemotong otomatis, perawatan alat

\begin{abstract}
Ngajum Gunung Kawi Village Malang Regency East Java there are many home industries of bamboo cutting production. The expansion marketing is resulted the workers in over time to process of cutting bamboo. The process of cutting bamboo is done manually, so it takes a long production time, high risk of work accidents, and more labors. The training conducted in collaboration with Partners to solve problems that faced by Partners, among others, training the use of automatic bamboo cutting tools, training and assistance of automatic equipment maintenance in bamboo cutting, as well as training and management assistance in bamboo cutting production. Tools made include bamboo cutting tools as a substitute for the process of manual cutting and bamboo smoothing tool after bamboo cut in the final stage. The design of the two tools can provide renewal of science in terms of science and technology, the implementation of microcontroller as a tool controller, minimize work accidents during bamboo cutting production, and optimize the production results in terms of production time. Production results increased after using the automatic bamboo cutting and bamboo smoothing tool, which is $25 \mathrm{~kg} /$ day to $100 \mathrm{~kg} /$ day.
\end{abstract}

Keywords: bamboo, microcontroller, automatic cutter, tool maintenance

\section{PENDAHULUAN}

Negara Indonesia merupakan negara yang beriklim tropis dengan hasil bumi yang banyak. Bambu merupakan salah satu hasil bumi di Indonesia yang dapat dimanfaatkan secara meluas untuk memenuhi berbagai keperluan manusia. Menurut (Handayani, 2009), di dunia ini terdapat kurang lebih 1250 jenis bambu dan terdapat kurang lebih 140 atau 11\% jenis bambu yang merupakan hasil bumi Indonesia. Bambu memiliki tekstur yang kuat, fleksibel dan memiliki corak yang bervariasi pada permukaan kulitnya. Ketersediaan bambu yang melimpah masih belum diimbangi dengan kesadaran masyakarat bahwasannya setelah bambu diolah akan menghasilkan nilai jual (Sulastiningsih, 2008). Adapun hasil olahan bambu dapat dimanfaatkan untuk bahan bangunan rumah, interior rumah, alat pertanian, alat makan, tusuk sate, sangkar burung, bahkan digunakan untuk media karya para seniman (Jana, 2007).

Di Desa Ngajum Gunung Kawi Kabupaten Malang Jawa Timur terdapat banyak home industri produksi potongan bambu yang digunakan untuk dupa dan tusuk sate. Pemasaran yang luas, mengakibatkan pekerja kuwalahan dalam proses pemotongan bambu. Proses pemotongan bambu dilakukan secara manual, sehingga membutuhkan waktu produksi yang lama dan tenaga yang lebih. Selain itu, adanya proses pemotongan bambu manual dapat mengakibatkan persentase tingginya kecelakaan kerja. Selain proses pemotongan manual, kendala lain yang dihadapi baik Mitra I maupun Mitra II adalah sulitnya bahan baku produksi di musim-musim tertentu. Jika bahan baku sulit maka Mitra akan mendatangkan bahan baku dari daerah lain, contohnya blitar. Adapun Mitra I dan Mitra II dari pelaksana IbM merupakan industri rumah tangga yang membentuk kelompok produksi pemotongan bambu.

Mitra I berdiri pada tahun 1995 dengan jumlah pekerja 3 orang. Dalam sehari dapat mengerjakan 1 batang bambu dengan ukuran 18 meter. Sedangkan pada Mitra II berdiri pada tahun 1996 dengan jumlah pekerja sebanyak 5 orang. Jenis bambu yang digunakan oleh kedua Mitra ditunjukkan pada Gambar 1 (a). 


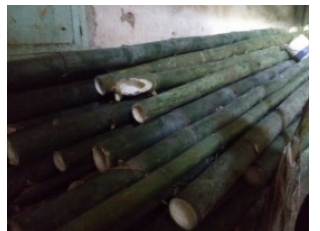

(a)

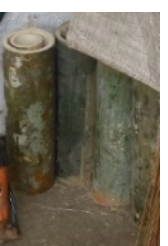

(b)

Gambar 1. (a) Bambu yang digunakan (b) Potongan Bambu

Mitra 1 dan Mitra II memproses pemotongan bambu dengan proses yang sama. Berdasarkan Gambar 1(b) bambu tersebut diproses dengan cara memotong bambu tersebut dengan ukuran panjang kurang lebih 22 $\mathrm{cm}, 29 \mathrm{~cm}$, dan $38 \mathrm{~cm}$. Proses pemotongan bambu secara manual ditunjukkan pada Gambar 2.

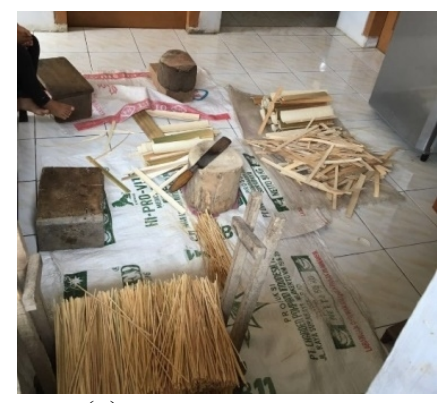

(a)

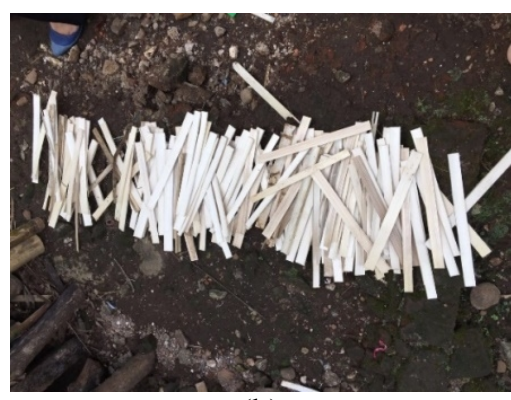

(b)

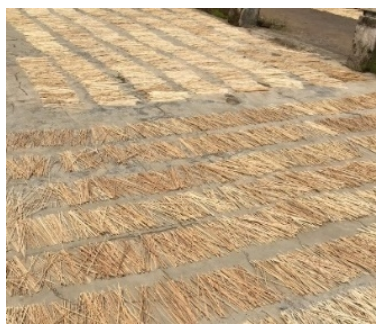

(c)

Gambar 2. (a) Proses Pemotongan Bambu secara manual (b) Hasil Potongan Bambu Sedang (c) Hasil Potongan Bambu Akhir

Berdasarkan Gambar 2 (a) merupakan proses pemotongan bambu secara keseluruhan yang dilakukan dengan manual. Ditinjau dari proses pemotongannya, persentase kecelakaan kerja (contohnya tangan terkena pisau) sangat tinggi. Waktu yang dibutuhkan juga lebih banyak dan tenaga manusia yang cukup besar. Proses dimulai dengan memotong bambu dalam ukuran $22 \mathrm{~cm}, 29 \mathrm{~cm}$, dan $38 \mathrm{~cm}$, kulit bambu tersebut dikupas (dibersihkan).

Gambar 2 (b) menunjukkan hasil potongan bambu, dimana 1 lingkar bambu dibagi menjadi 32 potong. Kemudian bambu tersebut dipotong dalam ukuran kecil, ditunjukkan pada Gambar 2 (c). Selanjutnya bambu yang telah dipotong dalam ukuran kecil dijemur, dimana proses penjemuran membutuhkan waktu 1 hari. Setelah proses penjemuran, dilakukan proses penghalusan pada potongan bambu tersebut. Pada Mitra II, proses penghalusan dilakukan dengan alat yang dibuat manual dengan memanfaatkan dinamo dan roda gila. Adapun alat yang digunakan oleh Mitra II ditunjukkan pada Gambar 3.

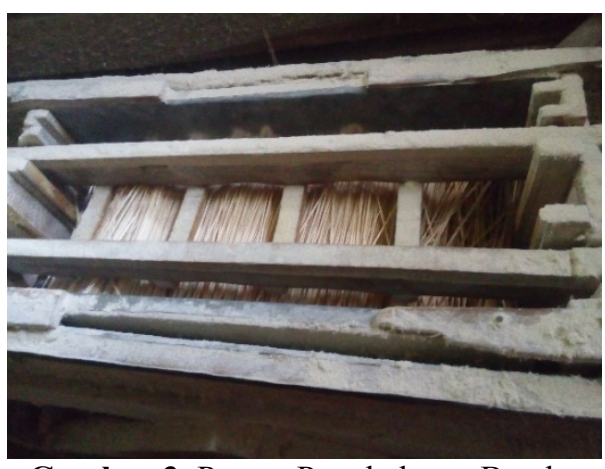

Gambar 3. Proses Penghalusan Bambu

Pada Gambar 3 pekerja Mitra II memanfaatkan dinamo yang dapat menggerakkan kayu yang terpasang di atas bambu. Dengan waktu kurang lebih 1 jam, serabut bambu dapat dihaluskan. Sedangkan pada Mitra I 
masih belum memiliki alat untuk penghalus bambu. Mitra I meminjam alat dengan biaya Rp 40.000 untuk 1 ikat bambu sekali proses penghalusan. Di Desa Ngajum Gunung Kawi, terdapat sebuah alat pemotong bambu otomatis. Namun, pengrajin bambu sulit memiliki alat tersebut dikarenakan harga yang sangat mahal, yaitu mencapai harga Rp 6.000.000.

Kedua Mitra tersebut memiliki 2 pokok kegiatan yang sama, yaitu produksi dan manajemen produk. Kegiatan produksi merupakan kegiatan yang dapat menghasilkan suatu produk. Sedangkan manajemen produk mencakup kegiatan pengolahan produk yang dimulai dari pengadaan bahan dasar sampai produk siap dipasarkan ke masyarakat. Dalam proses produksi penjualan bambu ditunjukkan pada Gambar 4.

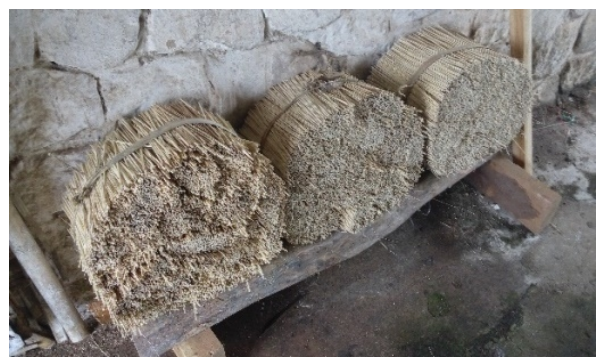

Gambar 4. Hasil Potongan Bambu yang Siap Dijual

Berdasarkan Gambar 4, satu ikat bambu merupakan hasil dari potongan bambu sepanjang 18 meter. Harga satu ikat bambu adalah Rp 100.000 dengan berat 1 kwintal. Dalam satu hari, mitra dapat menjual kurang lebih 1 ikat bambu. Namun, jika cuaca tidak panas, maka proses pengeringan bambu dapat memakan waktu hingga lebih dari 1 hari. Hal tersebut mengakibatkan penjualan bambu tidak selalu terjadi setiap hari. Sehingga, dibutuhkan pembukuan penjualan untuk mencatat penghasilan yang dilakukan. Pemasaran yang dilakukan Mitra I dan Mitra II juga memiliki kesamaan. Dimana setelah proses produksi bambu diikat dengan berat ikatan adalah 1 kwintal untuk selanjutnya dijual.

Masalah yang dihadapi kedua mitra dalam hal pencatatan pembukuan adalah sama, yaitu pembukuan hasil produksi dan penjualan tidak tercatat dengan baik. Sehingga, sering terjadi selisih perhitungan pada hasil dari laba yang diperoleh. Selain itu, tidak adanya pencacatan penjualan mengakibatkan Mitra kesulitan dalam melakukan peramalan produksi selanjutnya.

\section{METODE PELAKSANAAN}

\subsection{Perancangan Alat}

Alat yang digunakan meliputi alat pemotong bambu otomatis berbasis mikrokontroler dan alat penghalus bambu berbasis timer. Adapun perancangan alat dipisahkan menjadi 2, yaitu perancangan mekanik dan perancangan elektrik.

Perancangan mekanik untuk alat pemotong bambu otomatis membutuhkan spesifikasi antara lain: Gergaji Listrik $220 \mathrm{~V}$, Besi Hollow, 1 sensor proximity, 2 tombol pilihan otomatis dan manual, 2 Led Indikator, 1 suplai daya 5 Volt, 1 Mikrokontroler, dan 1 Stop Kontak Relay. Rangka alat pemotong bambu dibentuk seperti meja dan terdapat penopong untuk menahan bambu saat pemotongan agar tidak bergerak, kerangka yang digunakan berbahan besi, dan terdiri dari motor AC yang digunakan sebagai pemutar gigi pisau untuk pemotong. Perancangan elektrik untuk pemotong bambu otomatis ditunjukkan pada Gambar 5.

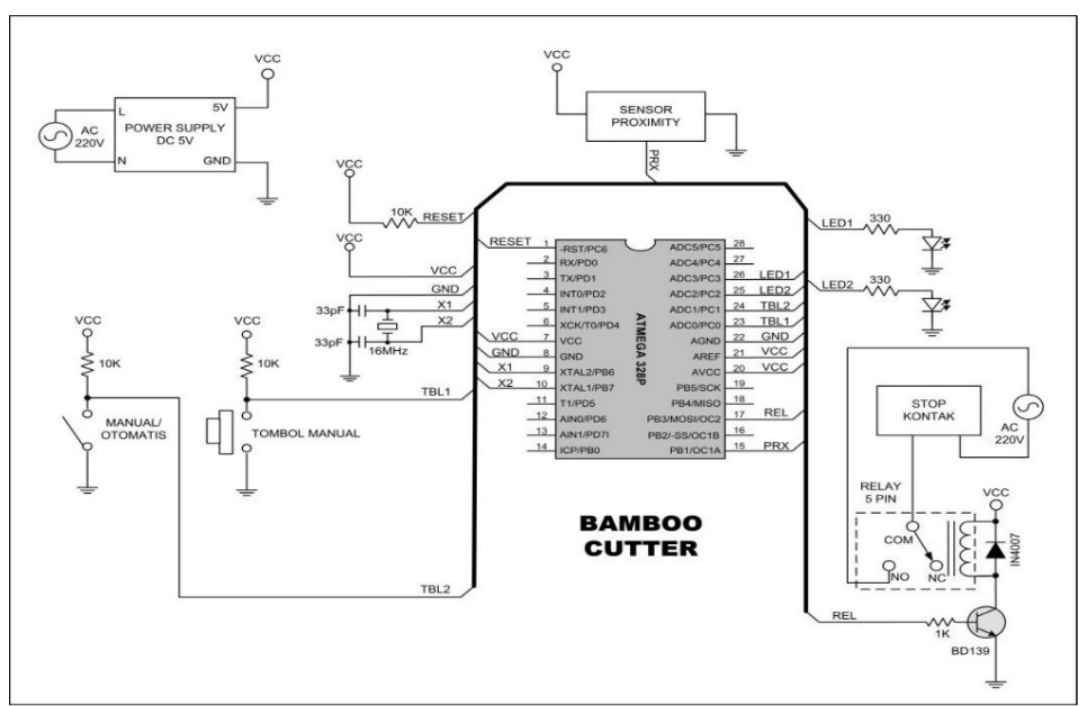

Gambar 5. Skema Rangkaian Elektrik Pemotong Bambu Otomatis 
Dari Gambar 5 menunjukkan bahwa sensor yang digunakan adalah sensor proximity. Tujuannya adalah untuk menentukan jarak bambu yang akan dipotong dan memberikan informasi kepada mikrokontroler untuk mulai mengaktifkan cutter / pemotong (Cekdin, 2017). Isi listing program yang ditanamkan pada mikrokontroler menggunakan bahasa pemrograman basic pada BASCOM-AVR (Setiawan, 2011). Listing program yang digunakan adalah sebagai berikut:

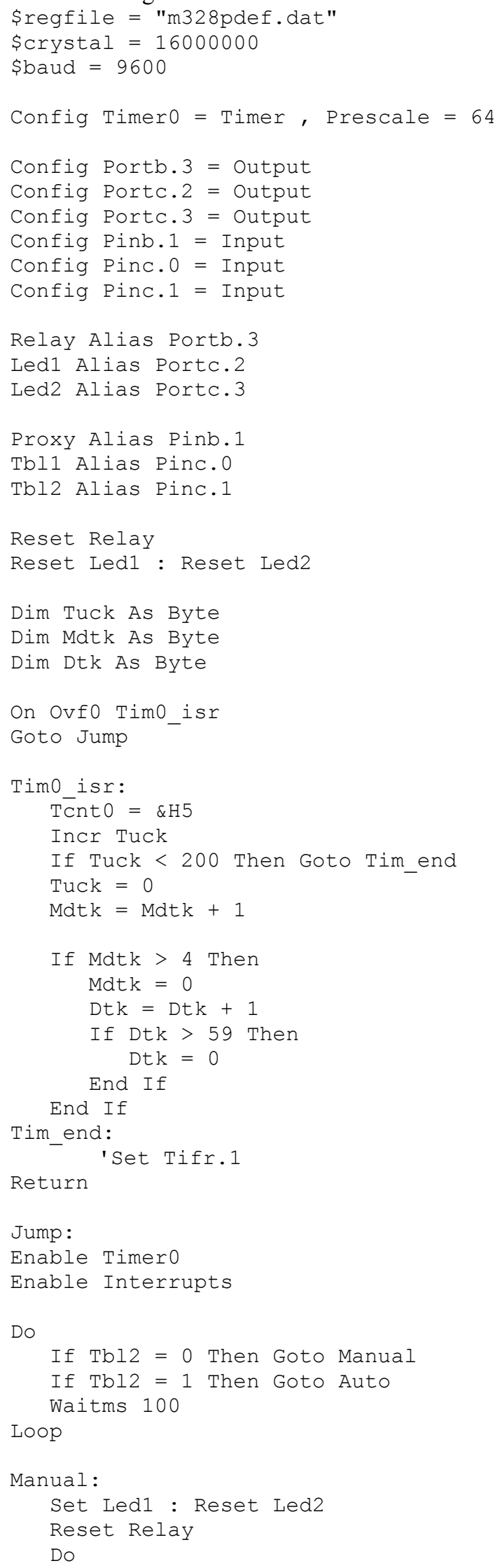




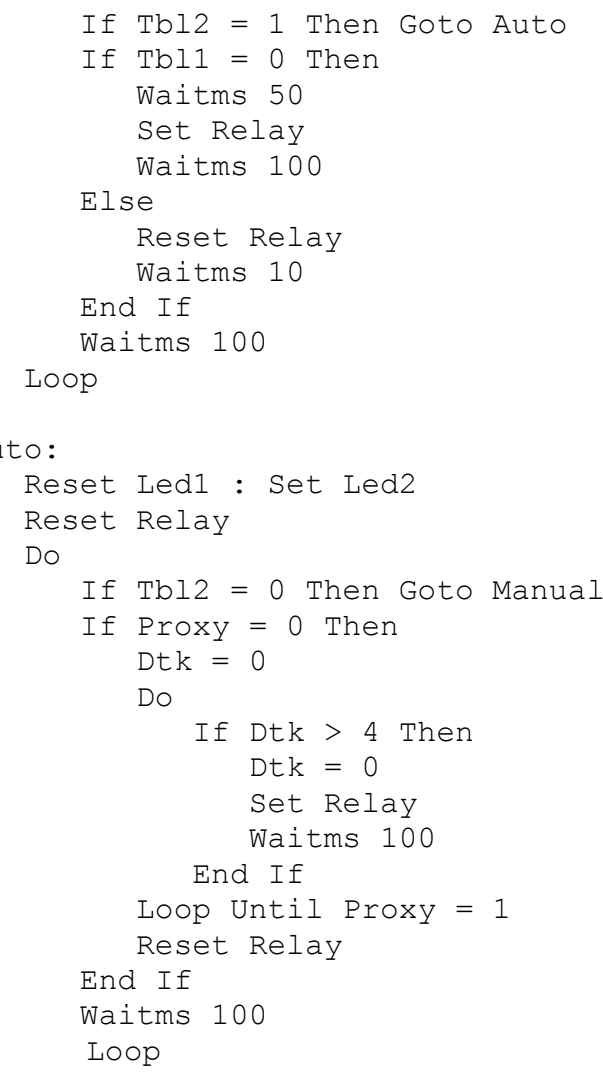

Perancangan mekanik untuk alat penghalus bambu membutuhkan spesifikasi antara lain, 1 Motor AC 1400 RPM, 1 Roda Puley diameter 30 CM, Besi Hollow, 1 Suplai daya 5 Volt, 3 Tombol pilihan menu waktu, 1 stop kontak relay, dan 1 Mikrokontroler sebagai pengendali utama dan LCD. Kinerja alat penghalus bambu adalah dengan memilih pengaturan waktu lamanya alat tersebut bekerja, yaitu selama 30, 60, atau 90 menit. Adapun perancangan elektrik alat penghalus bambu ditunjukkan pada Gambar 6.

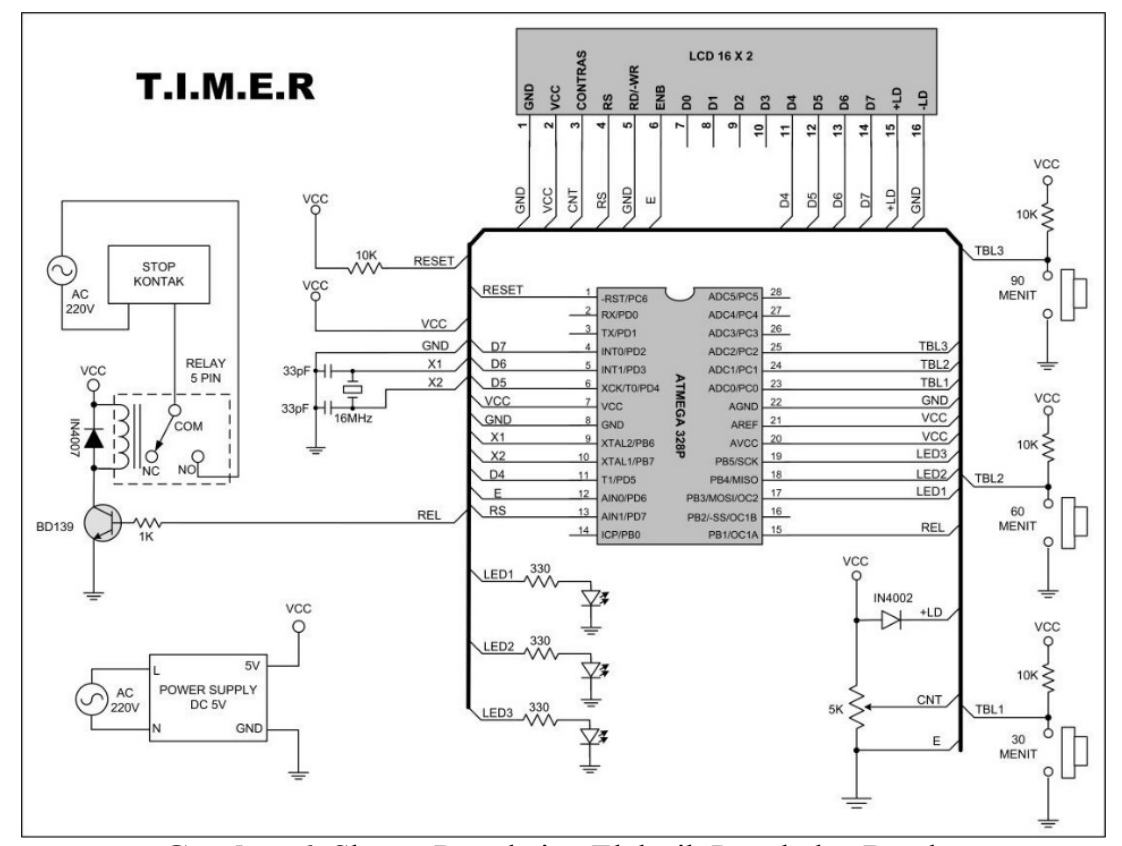

Gambar 6. Skema Rangkaian Elektrik Penghalus Bambu

\subsection{Perancangan Pelaksanaan}

Metode pelaksanaan dalam kegiatan pelatihan alat pemotong bambu otomatis berbasis mikrokontroler menuju kampong produktif di Desa Ngajum Gunung Kawi Malang dapat ditunjukkan pada Gambar 7. 


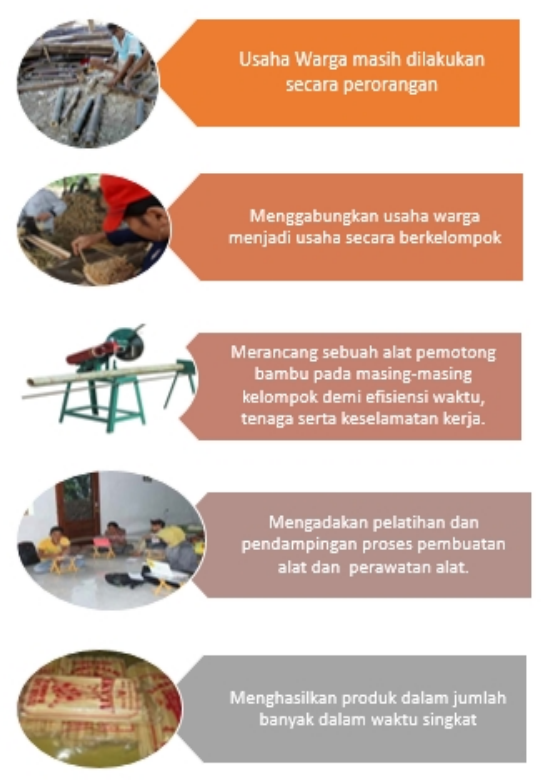

Gambar 7. Metode Pelaksanaan Kegiatan Pelatihan

Pemecahan dalam bentuk perancangan alat adalah salah satu alternatif pemecahan masalah, yaitu mengubah sistem produksi pemotongan bambu yang manual menjadi otomatis, yaitu dengan merancang sebuah alat uji coba yang akan disimulasikan pada sebuah kelompok usaha. Hal ini memiliki tujuan, meningkatkan taraf sumber daya manusia dengan melatih merancang sebuah alat, kemudian mensimulasikan serta menguji coba langsung pada lapangan. Dari Gambar 7 dapat dijelaskan runtutan kegiatan yang dilakukan yaitu:

1. Perancangan mekanik alat (mekanik, elektrik, dan software) pemotong bambu

2. Melaksanakan pelatihan dan pembimbingan dalam perancangan mekanik (kerangka alat) alat pemotong dan penghalus bambu

3. Melaksanakan pelatihan dan pembimbingan dalam perancangan elektrik (merakit komponen elektronika) alat pemotongan dan penghalus bambu

4. Melaksanakan pelatihan dan pembimbingan dalam perancangan perangkat lunak (software) sebagai interface microcontroller.

5. Melaksanakan pelatihan dan pendampingan dalam perancangan alat secara keseluruhan, yaitu menghubungkan mekanik, elektrik, dan software kepada kelompok masyarakat di kedua mitra IbM

6. Melaksanakan pelatihan dan pendampingan kepada kelompok masyarakat di kedua mitra IbM dalam maintenance alat pemotong bambu dan manajemen produksi untuk mempermudah pecatatan penjualan pada Mitra.

\section{HASIL DAN PEMBAHASAN}

Alat pemotong bambu menggunakan gergaji listrik dengan tegangan 220 volt $50-60 \mathrm{~Hz}$ dan daya sebesar 700 watt. Alat pemotong bambu otomatis ditunjukkan pada Gambar 8.

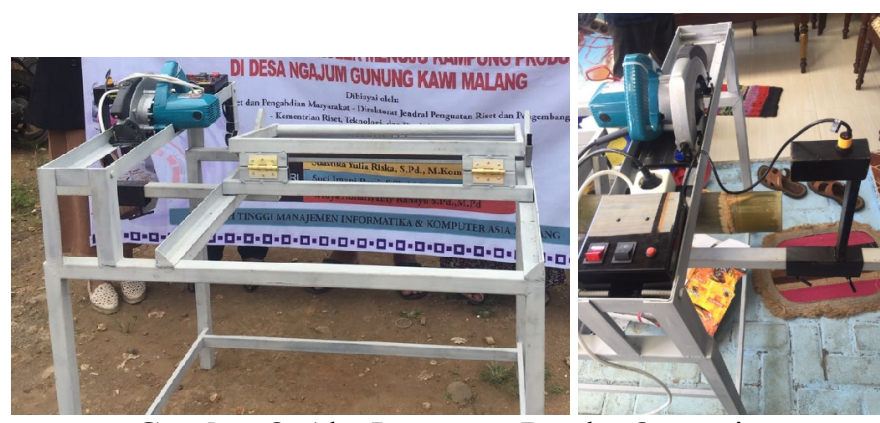

Gambar 8. Alat Pemotong Bambu Otomatis

Alat pemotong bambu dapat dilakukan secara manual dan otomatis. Cara manual untuk alat pemotong bambu adalah dengan menyalakan/mematikan gergaji dari saklar yang tersedia. Sedangkan cara otomatis dilakukan dengan cara deteksi sensor. Cara kerja sensor adalah dengan meletakkan bagian bambu di bawah sensor. Ketika sensor mendeteksi adanya bambu, otomatis gergaji listrik akan menyala. Dan gergaji listrik akan berhenti secara otomatis jika bambu tidak terdeteksi oleh sensor. 
Alat penghalus bambu ditunjukkan pada Gambar 9. Pada alat penghalus bambu alat yang dibuat dapat secara otomatis berhenti sesuai dengan waktu yang dipilih. Hal tersebut dapat memudahkan masyarakat, karena tidak perlu menunggu saat proses penghalusan potongan bambu. Pada alat ini juga dapat digunakan untuk berbagai ukuran bambu. Sehingga disalah satu plat(sisi) kotak penghalus dapat digeser sesuai dengan kebutuhan.

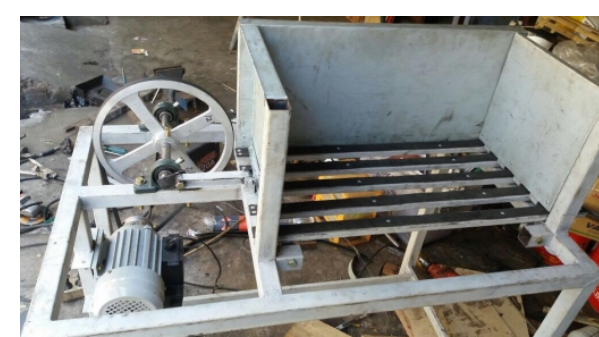

Gambar 9. Alat Penghalus Bambu Otomatis

Adapun variasi lamanya alat penghalus bekerja adalah 30, 60, atau 90 menit yang ditunjukkan pada Gambar 10. Tombol merah menunjukkan waktu 30 menit, tombol kuning menunjukkan waktu 60 menit, dan tombol merah menunjukkan waktu 90 menit. Cara kerja alat penghalus bambu adalah dengan menghubungkan kotak rangkaian elektrik penghalus bambu pada Gambar 10 dengan sumber tegangan. Kemudian menghubungkan motor listrik mekanik alat pemotong bambu pada Gambar 9 dengan kotak rangkaian elektrik.

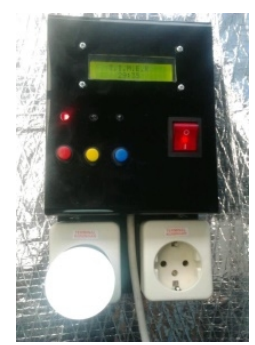

Gambar 10 Komponen Elektrik Penghalus Bambu

Dari Gambar 10 menunjukkan rancangan box elektrik yang berisi komponen elektronik yang berfungsi untuk mengatur waktu alat bekerja, dibagi dalam 3 durasi waktu, yaitu 30 menit, 60 menit, dan 90 menit. Alat dilengkapi dengan LCD yang berfungsi menampilkan waktu hitung mundur dari waktu yang telah diatur, selain itu tombol on-off untuk mengaktifkan alat dan tiga tombol untuk pilihan waktu yang diinginkan untuk mengaktifkan alat. Mikrokontroller sebagai pengendali waktu pada alat atau sebagai timer dan pengolah data untuk ditampilkan pada LCD.

Pada saat kegiatan pelatihan alat pemotong dan penghalus bambu otomatis antusias warga sangat baik, karena dapat meringankan pekerjaan yang mereka lakukan. Jalannya kegiatan ini ditunjukkan oleh Gambar 11, Gambar 12, Gambar 13, dan Gambar 14.

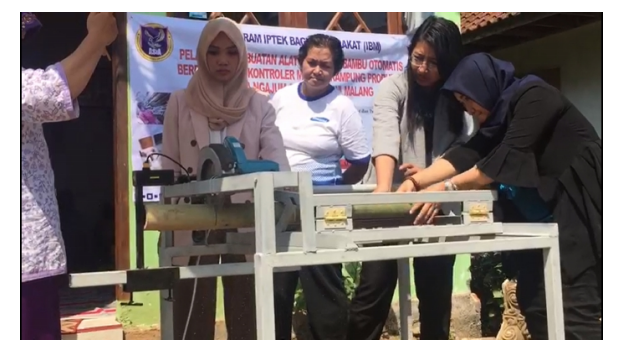

Gambar 11. Kegiatan Pelatihan Alat Pemotong Bambu

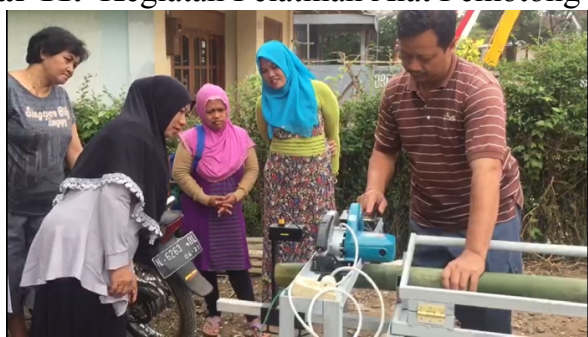

Gambar 12. Masyarakat Mencoba Menggunakan Alat Pemotong Bambu 


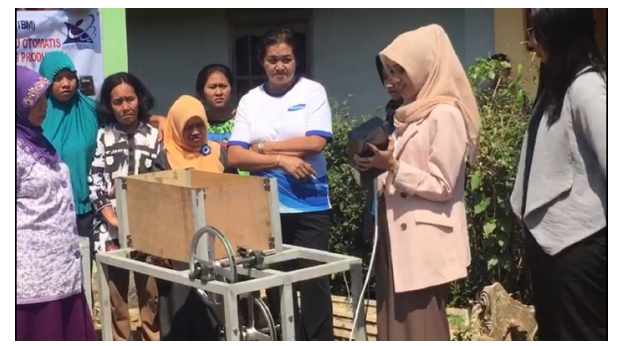

Gambar 13. Kegiatan Pelatihan Alat Penghalus Bambu

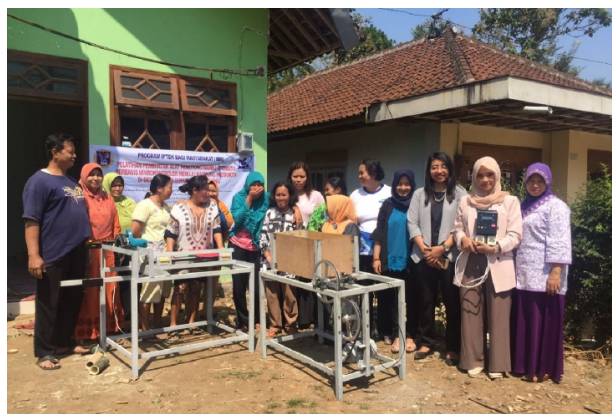

Gambar 14. Dokumentasi Setelah Pelatihan Dilaksanakan

Hasil yang didapatkan dari pelatihan alat pemotong dan penghalus bambu ini sangat berpengaruh pada hasil produksi potongan bambu yang digunakan untuk dupa sebagai kebutuhan pabrik. Hasil potongan bambu ditunjukkan pada Gambar 15.

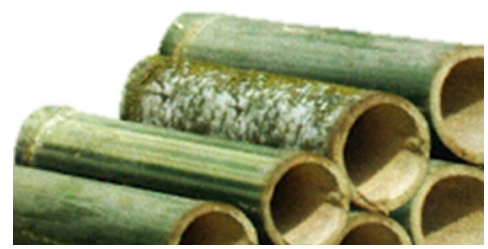

Gambar 15. Hasil Potongan Bambu dengan Alat Pemotong Bambu Otomatis

Sebelum menggunakan alat pemotong dan penghalus bambu otomatis, produksi potongan bambu yang dihasilkan adalah $25 \mathrm{~kg}$ /hari. Setelah menggunakan alat pemotong dan penghalus bambu otomatis, produksi potongan bambu meningkat dengan pesat, yaitu $100 \mathrm{~kg} / \mathrm{hari}$. Adapun proses penghalus bambu rata-rata bekerja selama 30 menit untuk $10 \mathrm{~kg}$ bambu. Sehingga proses penghalusan bambu dapat dilakukan selama 5 jam dalam sehari.

\section{KESIMPULAN DAN SARAN}

Permasalahan yang dihadapi baik Mitra I maupun Mitra II tidak jauh berbeda. Permasalahan utama yang dihadapi kedua mitra adalah proses pemotongan bambu secara manual yang mengakibatkan kebutuhan tenaga manusia lebih banyak dan memakan waktu yang lama. Selain itu adanya proses pemotongan manual mengakibatkan tingginya resiko kecelakaan kerja. Untuk mengatasi permasalahan tersebut diadakan pelatihan pemotong dan penghalus bambu otomatis berbasis mikrokontroler. Pada alat pemotong bambu otomatis, dibuat dua mode yaitu manual dan otomatis. Mode manual bekerja dengan cara menekan saklar untuk menggerakkan gergaji listrik, dan mode otomatis bekerja dengan cara sensor mendeteksi adanya bambu. Jika saklar mendeteksi bambu, maka secara otomatis gergaji listrik akan bergerak. Pada alat penghalus bambu menggunakan system timer, dimana lamanya alat beroperasi dapat diatur, yaitu 30 menit, 60 menit, dan 90 menit.

Hasil dari pelatihan alat pemotong dan penghalus bambu otomatis yang dilakukan, masyarakat sangat antusias. Masyarakat merasa adanya kemudahan dalam pekerjaan yang selama ini dilakukan secara manual. Selain itu adanya alat tersebut dapat meningkatkan hasil produksi yang sebelumnya menghasilkan $25 \mathrm{~kg} / \mathrm{hari}$, dapat meningkat menjadi $100 \mathrm{~kg} /$ hari. Sehingga, waktu yang dibutuhkan untuk produksi lebih efisien.

\section{DAFTAR RUJUKAN}

Cekdin, Cekmas. Barlian, Taufik. (2017). Rangkaian Listrik. Yogyakarta: Andi.

Handayani, S. (2009). Arsitektur dan Lingkungan. Bandung: Universitas Pendidikan Indonesia.

Jana, I Made. (2007). Pengolahan Bambu Sebagai Produk Kerajinan ditengah Lesunya Kepariwisataan Di Bali. 
Sulastiningsih, I.M. (2008). Teknik Pembuatan Bambu Lamina. Penelitian pada Pusat Litbang Keteknikan Kehutanan dan Pengolahan Hasil Hutan. FSRD.

Setiawan, Afrie. (2011). 20 Aplikasi Mikrokontroler ATMega 8535 \& ATMega 16 Meggunakan Bascom-AVR. Yogyakarta: Andi. 